\title{
花粉揭示的青藏高原西南部塔若错全新世以来 植被与气候变化
}

\author{
马庆峰 ${ }^{(12 *}$ ，朱立平 ${ }^{(1 *}$ ，吕新苗 ${ }^{(1)}$, 郭允 ${ }^{(1) 2}$ ，鞠建廷 ${ }^{(1)}$ ，王君波 ${ }^{(1)}$, 汪勇 ${ }^{(1)}$, 唐领余 ${ }^{(3)}$ \\ (1) 中国科学院青藏高原研究所, 环境变化与地表过程重点实验室, 北京 100101; \\ (2) 中国科学院大学, 北京 100049 ; \\ (3) 中国科学院南京地质古生物研究所, 现代古生物学和地层学国家重点实验室, 南京 210008 \\ * 联系人, E-mail: maqingfeng@itpcas.ac.cn; lpzhu@itpcas.ac.cn
}

2014-02-22 收稿, 2014-05-30 接受, 2014-08-04 网络版发表

中国科学院战略性先导科技专项(XDB03030400, XDA05120300)、国家科技基础性工作专项重点项目(2012FY111400)、国家自然科学基金 重大项目(41190082)和国家自然科学基金(41171162)资助

摘要 利用活塞采样器在位于青藏高原西南部塔若错 $60 \mathrm{~m}$ 水深处获得 $3.1 \mathrm{~m}$ 沉积岩芯. 通过 $\mathrm{AMS}^{14} \mathrm{C}$ 测年、花粉、粒度和无机碳分析, 恢复了青藏高原西南部全新世以来的植被和气候变化. 结 果显示, 全新世初期(10200 8900 cal a BP), 植被由高寒草原向高寒草甸转换, 气候由冷干向暖湿 发展; 全新世早期(8900 7400 cal a BP), 植被由高寒草甸到高寒草原的转换, 气候相对千旱, 但偏 暖; 全新世中期(7400 3300 cal a BP), 植被从高寒草原向高寒草甸或草甸化草原转换, 气候以冷湿 为主; 全新世晚期 (3300 cal a BP 至今), 植被逐渐被高寒草原取代, 气候变得寒冷干旱. 塔若错全 关键词

花粉

气候变化

全新世

塔若错

青藏高原 新世早期和中晚期的特征气候事件表明, 该地区明显受到西风区环境变化的影响, 而在全新世中 期更多受印度季风环流控制. 尤其是中晚全新世塔若错的湖泊沉积环境记录对于进一步阐述西风/ 季风在该地区的影响程度具有非常重要的意义.

青藏高原拥有巨大的面积和较高的海拔，诱发 了地球上最强烈的季风系统 ${ }^{[1]}$. 青藏高原处于北半球 中低纬度, 决定了其受东亚季风、印度季风和西风共 同影响 ${ }^{[2,3]}$. 青藏高原降水稳定同位素的观测和模拟 研究显示 ${ }^{[4]}$, 夏季, 暖湿的印度季风主要控制着高原 南部、东南部的大部分地区，并能够经常深人高原内 部; 冬季，横扫欧亚大陆的西风环流能够跃上高原， 对高原西部和北部造成深刻影响. 主要来自海洋的 印度季风和跨越大陆的西风带来不同的水热组合, 在地表过程上留下不同的烙印. 青藏高原地区的陆 上沉积记录忠实记录了二者影响下的古气候和古环 境变化. 利用湖泊沉积物在恢复青藏高原古气候方 面已经开展了较多工作 ${ }^{[5 ~ 15]}$. 目前的结果普遍认为, 该地区早中全新世暖湿, 晚全新世趋于冷干 ${ }^{[5 \sim 12]}$, 但
是，也有一些记录与此并不一致 ${ }^{[13 \sim 15]}$. 其原因一方 面可能是气候代用指标的多解性和不确定性引起的 解释偏差, 另一方面, 东部记录较多, 中西部偏少, 使我们还不能清唽全面地认识青藏高原地区全新世 气候变化的时空差异, 也就难以讨论不同历史时期 季风与西风影响的空间范围和程度.

目前的记录表明，全新世以来西风控制区的气 候水热组合与季风区具有不同特点 ${ }^{[2,16,17]}$. 印度季风 区石笋记录了早中全新世季风强盛，气候温暖湿润， 随着季风减退, 中晚全新世气候变得寒冷干燥 ${ }^{[17]}$. Chen 等人 ${ }^{[2]}$ 综合亚洲西风控制区的全新世古气候记 录, 提出与季风区不同的湿度 (降水)变化模式, 即 “西风模式”, 反映亚洲中部西风控制区早全新世干 旱, 中全新世气候最为湿润, 晚全新世湿度下降, 并 59: 4101-4114, doi: 10.1007/s11434-014-0505-1 
提出内陆干旱区在数百年尺度上, 气候表现为暖干冷湿组合 ${ }^{[18]}$. 位于高原西南部的塔若错, 处于西风 和印度季风的交汇区域 ${ }^{[2,19]}$, 其记录的气候变化对印 度季风和西风的影响程度较为敏感. 在不同的大气 环流及其带来的水热组合影响下, 流域植被的变迁, 如高寒草原与高寒草甸的更替, 会敏感地记录地质 时期不同的水热组合的变化. 该地区过去环境变化研 究薄弱, 具有较好年代控制和较高分辨率的古气候记 录较少 ${ }^{[15]}$. 本研究对塔若错 TRL11-2 钻孔进行了花 粉、粒度和无机碳(IC)分析, 在较好的年代控制下, 通 过对塔若错地区全新世的植被与气候变化进行重建, 讨论其气候变化的历史过程及其可能的影响因素.

\section{1 研究区域}

塔若错 $\left(31^{\circ} 03^{\prime} \sim 31^{\circ} 13^{\prime} \mathrm{N}, 83^{\circ} 55^{\prime} \sim 84^{\circ} 20^{\prime} \mathrm{E}\right)$ 位于青 藏高原西南部仲巴县, 冈底斯山脉北麓山间盆地内 (图 1). 盆地外围高山环绕, 东北部曾有出口, 为半 封闭湖泊 ${ }^{[20]}$. 湖泊呈东西向延伸, 面积为 $486.6 \mathrm{~km}^{2}$,
湖面海拔 $4566 \mathrm{~m}$, 实测最大水深 $132 \mathrm{~m}$. 集水面积 $6929.4 \mathrm{~km}^{2}$, 主要靠南部冰川融水径流补给. 湖区属 芫塘高寒草原半干旱气候, 据中国湖泊志 ${ }^{[20]}$ 记载该 湖区年均温 $0.0 \sim 2.0^{\circ} \mathrm{C}$, 年降水量 $200 \mathrm{~mm}$ 左右. 结合 2011 和 2012 年实地考察和前人工作, 发现草原和草甸 是该区两种主要的植被类型. $5100 \mathrm{~m}$ 以下, 以紫花针茅 (Stipa purpurea)群系占优势, 并有白草(Pennisetum flaccidum)、固沙草(Orinus thoroldii)、藏沙蒿(Artemisia wellbyi)、冻原白蒿(A. stracheyi)、羽状针茅(S. basiplumosa) 等; 5100 5400 m, 主要发育小峪草(Kobresia pygmaea) 和羊茅 (Festuca ovina) 组成的高山草甸或草 甸化草原; $5400 \mathrm{~m}$ 以上, 向高山冰缘植被过渡. 另外, 湖滨及河滩附近隐域性植被也较发育, 有三毛草 (Trisetum bifidum)、青藏苔草(Carex moorcroftii)、赖草 (Leymus secalinus $)$ 、藏西嵪草 $(K$. deasyi $)$ 和藏北嵩草 $(K$. littledale $i$ 等组成的草甸 ${ }^{[21]}$, 并有少量变色锦鸡儿 (Caragrnas versicdor) 灌丛和西藏沙棘 (Hippophae thibetana)灌丛, 主要分布于北部山坡和砾石质沙滩上.

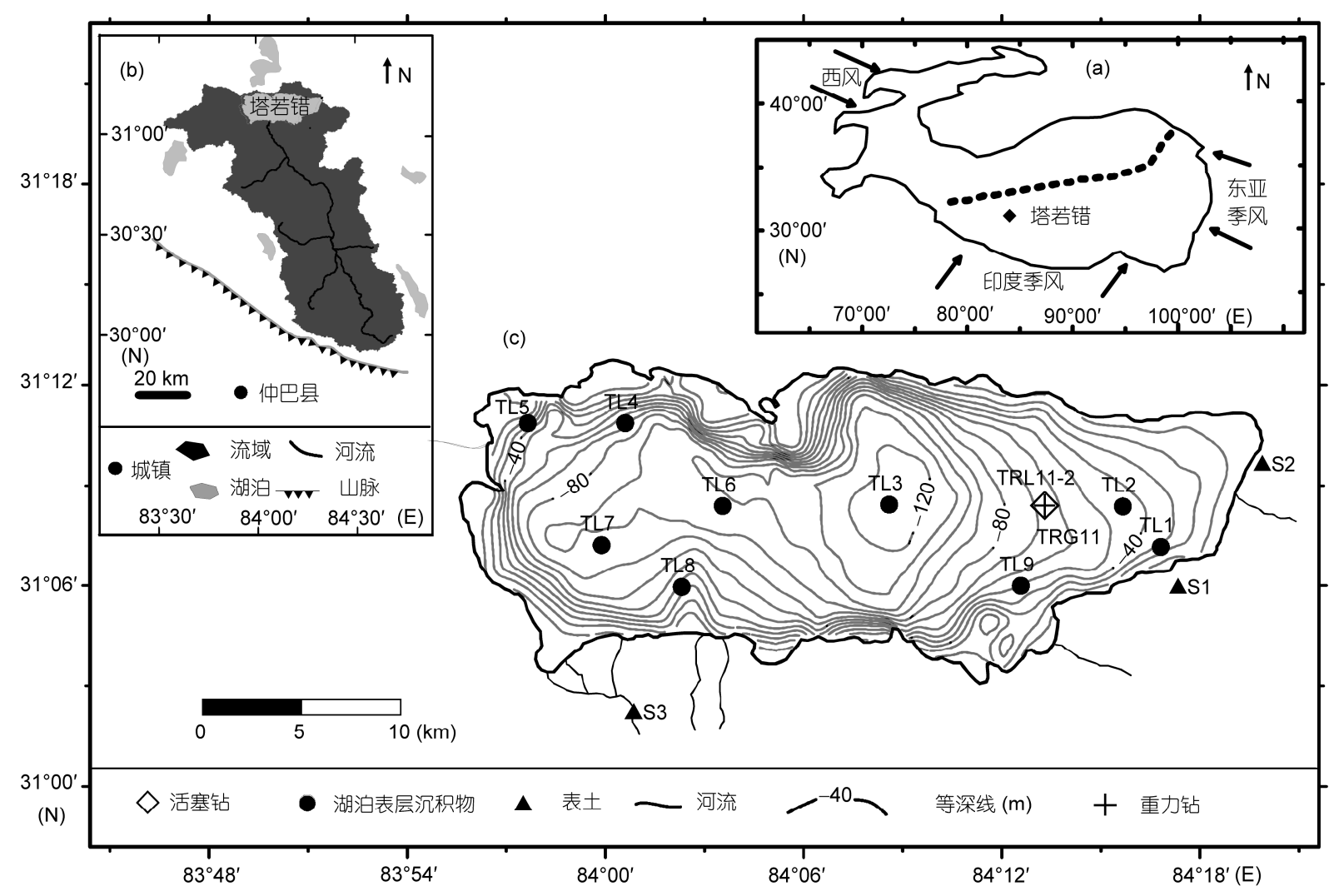

图 1 塔若错地理位置和流域基本情况示意图

(a) 塔若错地理位置(虚线为季风与西风界线, 参照文献[2]); (b) 塔若错流域概况及主要的补给河流; (c) 塔若错水深分布及活塞钻、重力钻、表 层沉积物和周围表土等采样点的分布 


\section{2 材料和方法}

(i ) 样品采集. 2011 年 9 月, 利用活塞钻在塔 若错水深约 $60 \mathrm{~m}$ 处获取了长度 $310 \mathrm{~cm}$ 的岩芯 (TRL11-2), 在实验室以 $1 \mathrm{~cm}$ 间隔分样, 从中按 4 6 $\mathrm{cm}$ 间隔取出 65 块样品进行花粉分析. 并在活塞钻相 同位置, 采集了 1 根 $63 \mathrm{~cm}$ 的重力钻短湖芯(TRG11), 对上部 $15 \mathrm{~cm}$ 以 $0.5 \mathrm{~cm}$ 间距分样, 进行了 ${ }^{210} \mathrm{~Pb}$ 年代 测定. 根据塔若错水深不同, 采集了 9 个表层沉积物 样品, 并于塔若错周围采集了 3 块表土样品 (S1 S2 为草原植被覆盖, $S 3$ 为草甸植被覆盖)(图 1(c)).

(ii) 沉积物定年. 塔若错重力钻 TRG11 过剩 ${ }^{210} \mathrm{~Pb}$ 的测定在中国科学院青藏高原研究所进行, 所 用仪器为高纯锗谱仪 (ORTECGWL-120-15), 每个样 品测量时间为 $80000 \mathrm{~s}$. 对塔若错 TRL11-2 钻孔 15 个 不同深度的样品进行了 $\mathrm{AMS}^{14} \mathrm{C}$ 测年, 其中 7 和 132 $\mathrm{cm}$ 处的 2 个样品, 同时测定了沉积物全样和植物残 体的年代, 其余深度样品为沉积物全样的年龄. 年代 的测定在美国 Beta 实验室完成, 利用 IntCal09 程序 ${ }^{[22]}$ 对测定的 ${ }^{14} \mathrm{C}$ 年代进行了日历年龄校正.

(iii) 无机碳和粒度测定. 无机碳(IC)和粒度的 测定在中国科学院青藏高原研究所完成. 测量 IC 使 用的仪器为 Shimadzu TOC-VCPH, 测量粒度使用的 仪器是 Microtrac S3500 激光粒度分析仪, 测量粒径 范围为 $2 \sim 2000 \mu \mathrm{m}$.

(iv) 花粉分析. 花粉的提取过程中, 首先称取 干样约 $5 \mathrm{~g}$ (沉积物样品)或 $20 \mathrm{~g}$ (表土样品), 每个样品 加人 1 片石松狍子片(18583 粒/片), 而后经 $10 \%$ 的 $\mathrm{HCl} 、 10 \%$ 的 $\mathrm{NaOH} 、 40 \%$ 的 $\mathrm{HF}$ 处理和硫酸乙酸酤处 理, 最后经 $10 \mu \mathrm{m}$ 尼龙布过滤后离心富集. 花粉的鉴 定在ZIESS 显微镜下放大 400 倍进行, 鉴定依据参照 相关文献[23,24], 每个样品至少鉴定 300 粒. 花粉图 谱的绘制由 Tilia 2.0 软件 ${ }^{[25]}$ 完成, 花粉分带参照了 TGView 中 CONISS 聚类分析的结果.

为了更好地认识主要花粉类型之间的关系, 对 TRL11-2 岩芯样品花粉百分含量数据进行降趋势对 应分析(DCA). 结果显示, 第一轴的梯度长度为 0.94 , 小于 2 个标准差(SD), 指示狍粉组合序列对环境变量 呈线性响应关系, 因此选用线性模型-主成分分析 (PCA) 对岩芯花粉谱进行排序分析 ${ }^{[26]}$. PCA 分析用 Canoco 4.5 来实现, 为了消除不同花粉科属数据间的 差异, 改善花粉科属的“信噪比”(signal to noise ratio),
花粉物种数据经过了 LOG 转化 ${ }^{[13,27,28]}$.

\section{3 结果}

\section{1 沉积物年代}

对与 TRL11-2 孔相同位置的重力钻 TRG11 进行 ${ }^{210} \mathrm{~Pb}$ 沉积速率分析, 通过 CRS 模型计算了湖芯上 部 $7 \mathrm{~cm}$ 的沉积速率, 并推导相应的沉积年代(表 1). 结果显示 2 和 $7 \mathrm{~cm}$ 处的年龄为 -25 和 $82 \mathrm{a} \mathrm{BP}$, 而同 深度活塞钻 $\mathrm{AMS}^{14} \mathrm{C}$ 测定的沉积物全样年龄(表 $\mathrm{S} 1$ ) 分别为 $1995 \pm 65$ 和 $3305 \pm 25$ a BP, 显示具有较大的碳 库效应, 需要予以剔除. 从钻孔中获得的 2 个植物残 体样品看, $7 \sim 8 \mathrm{~cm}$ 深度植物残体的 $\delta^{13} \mathrm{C}$ 为 $-23.2 \%$, 代表了陆生草本植物和水生植物的混合体 ${ }^{[29,30]}$, 因 此, 植物残体的年龄应较实际年龄老. 132 133 cm 深 度的植物残体因含量小, 未测量到 $\delta^{13} \mathrm{C}$ 值, 从表 $\mathrm{S} 1$ 结果看, 整个钻孔的全样有机质 $\delta^{13} \mathrm{C}$ 较为恒定, 认 为利用植物残体年龄得到的碳库效应在钻孔中也应 稳定, 但由于全样有机质含有非植物残体来源, 其年 龄与植物残体年龄的差值并不一定均一. 根据 ${ }^{14} \mathrm{C}$ 测 年推断的沉积速率和获得的 2 个植物残体年龄, 以 $20 \mathrm{~cm}$ 深度为界, 分 2 段进行了年代校正(表 S1). 20 $\mathrm{cm}$ 以上, $7 \mathrm{~cm}$ 处的沉积速率年龄为 $82 \mathrm{a} \mathrm{BP}\left({ }^{210} \mathrm{~Pb}\right.$ 测 定), 而其植物残体的年龄为 $2810 \pm 10 \mathrm{a} B \mathrm{BP}$, 因此, 植 物残体的碳库效应为 $2728 \mathrm{a}$, 该深度沉积物全样年代 为 $3305 \pm 25 \mathrm{a} \mathrm{BP}$, 比植物残体年龄偏老 $495 \mathrm{a}$, 因此, 沉积物全样的碳库效应为 3223 a. $20 \mathrm{~cm}$ 以下, $132 \mathrm{~cm}$ 处植物残体的碳库效应也是 $2728 \mathrm{a}$, 而该处沉积物全 样比植物残体年龄偏老 $755 \mathrm{a}$, 故沉积物全样的碳库 效应为 $3483 \mathrm{a}$. 对 $20 \mathrm{~cm}$ 以上和以下测定的沉积物全 样年代分别减去 3223 和 $3483 \mathrm{a}$, 即获得整个钻孔的 年代序列(表 S1). 深度为 217 和 $305 \mathrm{~cm}$ 的 2 个样品, 测年结果出现倒转, 考虑到样品质地及沉积速率等, 在建立年代序列时, 予以剔除. 对全部样品年代序列 进行了曲线拟合(图 2), 计算出每个深度的沉积物年龄.

\section{2 现代表层沉积/表土花粉组合}

塔若错不同水深表层沉积物花粉组合结果(图 S1) 显示, 蒿属(Artemisia)含量最高, 占 $42.9 \%$ 54.9\%, 其次是莎草科(Cyperaceae), 占 $8.1 \% \sim 17.4 \%$, 禾本科 (Poaceae)占 $5.9 \%$ 9.6\%. 乔木花粉含量较少, 主要有 松属(Pinus) $(3.2 \%) 、$ 常绿栋 $(6.3 \%)$ 、桦木属(Betula) 
表 1 塔若错 TRG11 湖芯顶部过剩 ${ }^{210} \mathrm{~Pb}$ 测试结果与年龄分析

\begin{tabular}{|c|c|c|c|c|c|c|c|}
\hline 样品号 & $\begin{array}{l}\text { 深度 } \\
(\mathrm{cm})\end{array}$ & $\begin{array}{l}{ }^{210} \mathrm{~Pb}_{\text {ex }} \\
(\mathrm{Bq})\end{array}$ & $\begin{array}{l}\text { 重量 } \\
(\mathrm{g})\end{array}$ & $\begin{array}{l}\text { 质量沉积速率 } \\
\left(\mathrm{mg} \mathrm{a}^{-1} \mathrm{~cm}^{-2}\right)\end{array}$ & $\begin{array}{c}\text { CRS 模型推算的沉积 } \\
\text { 时间 (a) }\end{array}$ & 年份 & $\begin{array}{c}{ }^{210} \mathrm{~Pb} \text { 推算的年龄 } \\
\text { (cal a BP) }\end{array}$ \\
\hline TRG11-1 & 0.5 & 214.14 & 5.65 & 17.52 & 0 & 2011 年 & -61 \\
\hline TRG11-2 & 1.0 & 115.38 & 5.37 & 19.16 & 17 & 1994 年 & -44 \\
\hline TRG11-3 & 1.5 & 69.45 & 6.28 & 23.65 & 27 & 1984 年 & -34 \\
\hline TRG11-4 & 2.0 & 67.16 & 4.90 & 18.29 & 36 & 1975 年 & -25 \\
\hline TRG11-5 & 2.5 & 31.94 & 5.46 & 29.02 & 45 & 1966 年 & -16 \\
\hline TRG11-6 & 3.0 & 27.31 & 4.42 & 27.70 & 51 & 1960 年 & -10 \\
\hline TRG11-7 & 3.5 & 21.50 & 4.85 & 29.97 & 57 & 1954 年 & -4 \\
\hline TRG11-8 & 4.0 & 25.84 & 4.95 & 21.21 & 62 & 1949 年 & 1 \\
\hline TRG11-9 & 4.5 & 33.32 & 4.12 & 12.97 & 69 & 1942 年 & 8 \\
\hline TRG11-10 & 5.0 & 6.72 & 4.73 & 45.26 & 81 & 1930 年 & 20 \\
\hline TRG11-11 & 5.5 & 7.90 & 4.55 & 34.84 & 84 & 1927 年 & 23 \\
\hline TRG11-12 & 6.0 & 19.78 & 4.86 & 12.27 & 88 & 1923 年 & 27 \\
\hline TRG11-13 & 6.5 & 23.55 & 5.27 & 6.63 & 102 & 1909 年 & 41 \\
\hline TRG11-14 & 7.0 & 13.02 & 3.64 & 3.39 & 143 & 1868 年 & 82 \\
\hline
\end{tabular}

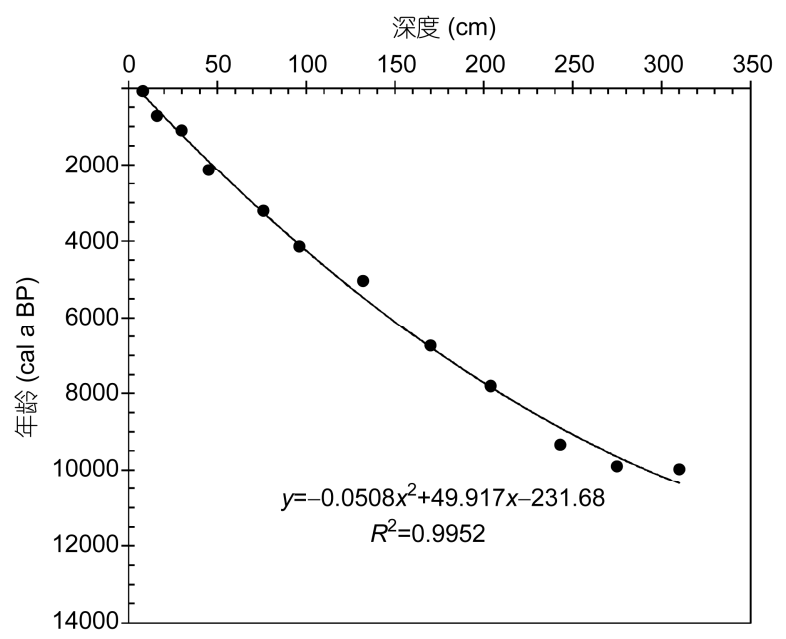

图 2 塔若错 TRL11-2 钻孔年代拟合曲线

$(2.3 \%)$ 和桤木属 $(A \ln u s)(2.4 \%)$. 现在塔若错流域内没 有乔木生长, 这些乔木花粉应该是风从远处携带而 来. 灌木花粉主要有萻薇科(Rosaceae)(2.2\%)、麻黄属 (Ephedra) $(0.3 \%)$ 和沙棘属(Hippophae) $(0.3 \%)$. 草本花 粉除蒿属、莎草科和禾本科以外, 还有藜科(Chenopodiaceae) $(2.5 \%) 、$ 毛茛科(Ranunculaceae)(1.4\%), 其 他花粉含量 $<1 \%$. 从不同水深的湖泊表层沉积物花 粉来看, 各个样品具有基本类似的花粉种属和含量, 反映了湖泊沉积物对流域花粉的富集及其在沉积过 程中的均匀分配作用. 而在湖泊周围的 3 个表土样品
中, 草原植被下的 $\mathrm{S} 1$ 和 $\mathrm{S} 2$ 样中, 蒿属含量最高(分别 为 $53 \%$ 和 $35 \%$ ), 其次是禾本科( $16 \%$ 和 $15 \%$ ) 和莎草科 $(13.8 \%$ 和 $15.7 \%)$; 而草甸植被下的 $\mathrm{S} 3$ 则是莎草科 $(41.5 \%)$ 和禾本科含量 $(44.3 \%)$ 高, 蒿属花粉含量 (3.4\%)低. 蒿属与莎草科花粉的比值(A/Cy)除在草甸 植被下的 S3 样品中小于 1 外, 在其他表土样品 S1 S2 和表层沉积物 TL1 TL9 中均大于 1 .

\section{3 钻孔沉积物花粉组合}

在塔若错 TRL11-2 孔 65 块花粉样品, 共鉴定出 58 个科属的花粉类型. 花粉类型以草本植物花粉为 主, 蒿属、莎草科和禾本科含量最为丰富, 三者之和 占花粉总数的 $61.4 \%$ $91.3 \%$, 其他草本花粉类型有藜 科、毛茛科、唇形科(Labiatae)、唐松草属(Thalictrum)、 十字花科(Cruciferae)、豆科(Leguminosae)、石竹科 (Caryophyllaceae)、蓼属(Polygonum)、紫苑属(Aster)、 葎草属(Humulus) 和马先蒿属(Pedicularis)等. 乔木花 粉 $(5.9 \%)$ 有松属、云杉属、栎属、桦木属和桤木属等. 灌木花粉 $(6.6 \%)$ 主要有菩薇科、麻黄属、沙棘属和白 刺属(Nitraria)等.

根据 TRL11-2 孔主要花粉含量的变化, 利用聚 类分析, 将整个钻孔花粉组合分为 4 个带(图 3).

TRL-1 带(303 242 cm, 10200 8900 cal a BP): 花 粉浓度为整个钻孔最低, 平均只有 9040 粒/克. 蒿属 


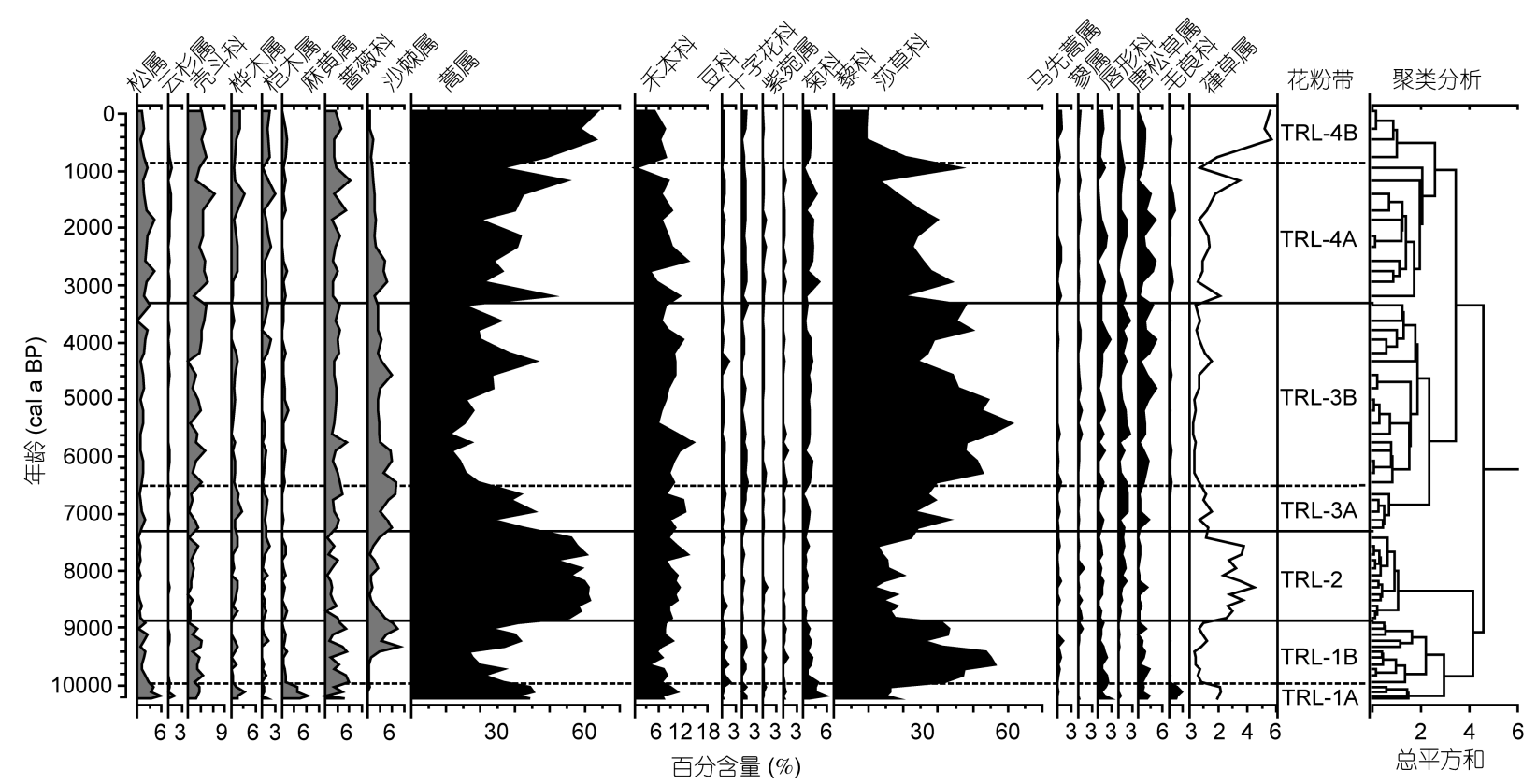

图 3 塔若错钻孔花粉百分含量及花粉分带

含量(31.6\%)较低, 而莎草科含量(36.3\%)较高. 莎草 科含量呈先增加后减少趋势, 在 $9600 \mathrm{cal} \mathrm{a} \mathrm{BP}$ 左右 达到峰值 $54.5 \%$. A/Cy 快速由 2 降到 0.6, 之后比较稳 定. 该带分为 2 个亚带 TRL-1A 和 TRL-1B.

TRL-1A 亚带(303 290 cm, 10200 9900 cal a BP): 莎草科含量 $(23 \%)$ 较低, 蒿属含量为 $38.3 \%$, 禾本科 含量 $8 \%$. 松属 $(3.8 \%)$ 、蓋科 $(3.3 \%)$ 和麻黄属 $(3.8 \%)$ 含 量为整个序列最高. $\mathrm{A} / \mathrm{Cy}$ 值较高, 平均为 1.8 .

TRL-1B 亚带(290 242 cm, 9900 8900 cal a BP): 本亚带蒿属含量 $(27.9 \%)$ 比较低, 而莎草科含量 (43.6\%)上升. 松属 $(1.4 \%)$ 和藜科 $(1.4 \%)$ 、麻黄属 $(0.6 \%)$ 等含量降低. $\mathrm{A} / \mathrm{Cy}$ 值为 0.7 , 较低而且波动不大.

TRL-2 带(242 188 cm, 8900 7400 cal a BP): 花 粉浓度平均为 26000 粒/克, 比上一阶段 TRL-1 显著 升高. 蒿属花粉含量平均为 $56.5 \%$, 为全序列最高; 而莎草科含量 $(20.6 \%)$ 为序列最低. 花粉谱以蒿属(莎 草科)含量快速上升(下降) 区别于上带. $\mathrm{A} / \mathrm{Cy}$ 值比较 高, 平均为 2.9 .

TRL-3 带(188 77 cm, 7400 3300 cal a BP): 花粉 浓度为 21000 粒/克, 较 TRL-2 略有降低, 花粉含量以 莎草科占优势, 蒿属比较低. 本带可进一步划分为 2 个亚带 TRL-3A 和 TRL-3B.

TRL-3A 亚带 $(188 \sim 163 \mathrm{~cm}, 7400 \sim 6500 \mathrm{cal}$ a BP): 花粉浓度平均为 26000 粒/克, 蒿属由 $55.8 \%$ 降至
$22.9 \%$ ，莎草科由 $26.6 \%$ 升至 $50.2 \%$ ，桦木属、蓄薇科、 沙棘属、唐松草属略有增加, 禾本科和其他花粉含量 变化不大. $\mathrm{A} / \mathrm{Cy}$ 由 3.8 降至 0.7 .

TRL-3B 亚带 $(163 \sim 77 \mathrm{~cm}, 6500 \sim 3300 \mathrm{cal}$ a BP): 花粉浓度平均为 19700 粒/克, 莎草科含量最高, 平 均含量 $44.2 \%$, 在 $5400 \mathrm{cal} \mathrm{a} \mathrm{BP}$ 左右达到 $61.2 \%$ 的峰 值; 蒿属含量显著降低, 平均 $23 \%$. 毛莨科、唐松草 属、唇形科、沙棘属、蓄薇科、栎属等花粉含量比 TRL-2 有所增加, 其他花粉没有明显变化, A/Cy 值比 较低, 平均为 0.6 .

TRL-4 带 $(77 \sim 0 \mathrm{~cm}, 3300 \mathrm{cal}$ a BP 至今): 蒿属含 量呈上升趋势, 莎草科含量下降. 乔木花粉中, 松 属、桦木属、桤木属、栎属含量较 TRL-2 和 TRL-3 有明显升高, 䔉科含量也有所增加. 本带可分为两个 亚带 TRL-4A 和 TRL-4B.

TRL-4A 亚带 $(77 \sim 23 \mathrm{~cm}, 3300 \sim 900 \mathrm{cal} \mathrm{a} \mathrm{BP})$ : 花 粉含量平均为 21000 粒/克, 蒿属含量升高, 平均为 $34 \%$; 莎草科含量下降, 平均为 $31 \%$; 禾本科花粉含 量 $8 \%$, 略有降低. 乔木花粉明显增加, 藜科花粉含 量上升, 平均 $1.8 \%$. A/Cy 值平均为 1.3 , 较 TRL-3 明 显升高.

TRL-4B 亚带 $(23 \sim 0 \mathrm{~cm}, 900 \mathrm{cal}$ a BP 至今): 花粉 浓度较高, 平均为 34000 粒/克, 蒿属由 $30.6 \%$ 升至 $64 \%$, 莎草科含量下降至 $11.2 \%$, 禾本科(7\%)也有所 
下降. 乔灌木花粉如松属 $(1.7 \%)$ 、桦木属 $(1.3 \%) 、$ 桤 木属 $(1.2 \%)$ 、栋属 $(2.3 \%)$ 、蔷薇科 $(2.7 \%) 、$ 藜科 $(1.4 \%)$ 含量较高, 其他花粉含量低于 $1 \%$. A/Cy 值由 0.7 升高 至 5.2 .

\section{4 粒度和无机碳含量}

塔若错 TRL11-2 孔平均粒径 $(M z)$ 结果(图 4)显示, 10200 9900 cal a BP, $M z(13.5 \sim 5.4 \mu \mathrm{m})$ 快速下降; 9900 9300 cal a BP, $M z$ 值比较低, 而且平稳, 平均 $4.6 \mu \mathrm{m} ; 9300 \sim 8900 \mathrm{cal} \mathrm{a} \mathrm{BP}, M z$ 突然由 $5.1 \mu \mathrm{m}$ 快速增 加到 $12.3 \mu \mathrm{m}$, 之后又快速下降至 $5.6 \mu \mathrm{m}$. 8900 6500 cal a BP, $M z(5.5 \sim 13.7 \mu \mathrm{m})$ 呈上升趋势. $6500 \mathrm{cal} \mathrm{a} \mathrm{BP}$ 左右, $M z$ 迅速下降, 并于 $6000 \mathrm{cal} \mathrm{a} \mathrm{BP}$ 左右降至 5.6 $\mu \mathrm{m}$. 之后, 一直呈增加趋势, 并于 4600 4200 cal a BP 出现谷值和 $2900 \mathrm{cal} \mathrm{a} \mathrm{BP}$ 左右出现峰值.

TRL11-2 钻孔无机碳 IC 含量(图 4)在 10200 9900 cal a BP 从 3.0\%快速降为 1.1\%; 9900 8900 cal a BP, IC 含量先降至 $0.21 \%$ (9400 cal a BP), 而后上升至 $0.89 \%$, 含量总体较低; 8900 6500 cal a BP, IC 含量 比较稳定，在 $0.58 \%$ $0.89 \%$ 之间波动，平均为 $0.76 \%$; 6500 6300 cal a BP, IC 含量持续下降, 至 $6300 \mathrm{cal} \mathrm{a}$ BP 左右降为 $0 ; 6300 \sim 1100 \mathrm{cal} \mathrm{a} \mathrm{BP}, \mathrm{IC}$ 含量一直为 0 ; $1100 \mathrm{cal}$ a BP 以来, IC 含量开始增加, 并升至 $1.4 \%$.

\section{4 讨论}

\section{1 花粉比值与花粉谱排序的意义}

花粉比值作为一种半定量的指标, 用来指示地 质时期气候和环境变化已有不少应用, 其中 $\mathrm{A} / \mathrm{C}($ 蒿 属与藜科花粉含量的比值 $)^{[5,8,13,31 ~ 34]}$ 和 $\mathrm{A} / \mathrm{Cy}$ (蒿属与 莎草科花粉含量的比值)在高原上较为常用. 因研究 区藜科花粉含量很低, 故本文未讨论 $\mathrm{A} / \mathrm{C}$ 的意义 ${ }^{[35]}$. $\mathrm{A} / \mathrm{Cy}$ 值可以指示草原/草甸的植被变化, 一般认为草 原区的 $\mathrm{A} / \mathrm{Cy}>1$, 草甸区的 $\mathrm{A} / \mathrm{Cy}<1^{[35,36]}$. 蒿属相对于 莎草科植物更喜暖干环境, 因而有学者将 $\mathrm{A} / \mathrm{Cy}$ (蒿属 和莎草科花粉含量比值)作为温度或湿度指标. Hezschuh 等人 ${ }^{[32]}$ 认为在青藏高原东部较湿润区, $\mathrm{A} / \mathrm{Cy}$ 值 可以指示夏季温度的变化, 而 Fowell 等人 ${ }^{[37]}$ 对 Telmen 湖研究认为, 在内陆干旱区, 蒿属和莎草科 花粉含量主要受控于湿度的差异. 这可能是因为两 者研究区不同, 控制植物生长最主要的限制因子有 差异. 塔若错地处青藏高原西南部半干旱区, 年降水 量仅为 $200 \mathrm{~mm}$ 左右. 蒿属和莎草科是该地区现代以 及钻孔最主要的花粉类型, 本文认为 $\mathrm{A} / \mathrm{Cy}$ 值主要反 映了湿度的差异.

对比湖泊表层沉积物与钻孔花粉组成, 结合现 代流域内没有乔木生长, 在对钻孔花粉谱进行主成

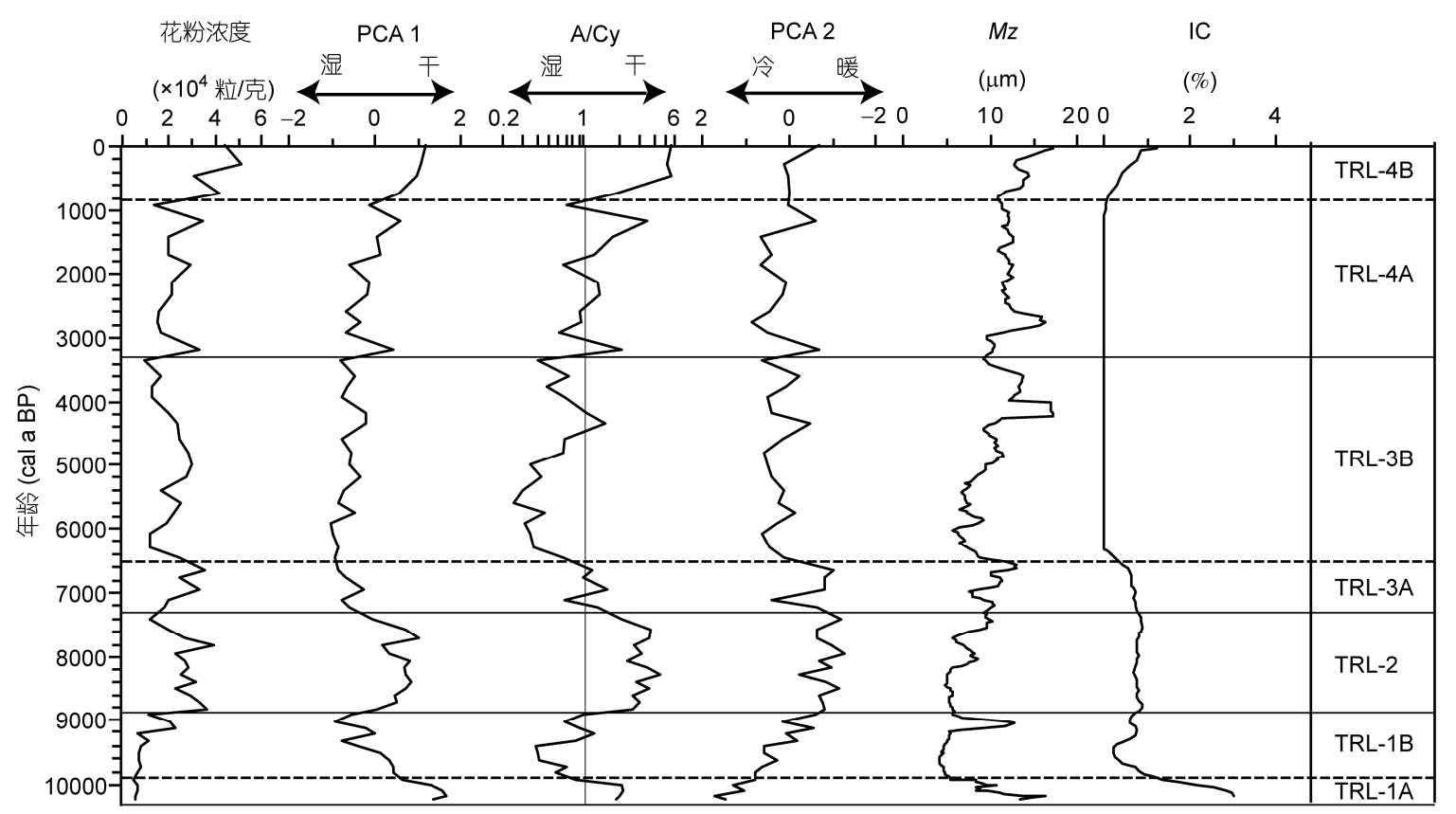

图 4 塔若错钻孔花粉指标主成分分析结果与平均粒径、无机碳之间的比较图 $\mathrm{A} / \mathrm{Cy}$ 为蒿属莎草科含量比值; $M z$, 平均粒径; IC, 无机碳 
分分析(PCA)时, 选取了 17 个主要的草本和灌木花 粉类型进行分析. PCA 结果如图 5, 第一主成分轴 (PCA 1) 和第二主成分轴(PCA 2)分别解释了 $25.9 \%$ 和 $21.7 \%$ 的花粉谱变化信息. PCA 1 正载荷主要是蒿属、 麻黄属、莍科等, 为高寒草原与高寒半荒漠和荒漠成 分, 负载荷主要是莎草科、毛莨科、唐松草属等, 为 高寒草甸成分, 故第一主成分轴主要反映了干湿变 化. 正值表示趋向干旱, 负值表示趋向湿润. PCA 2 正载荷的主要是莎草科、毛莨科、麻黄属、藜科等, 为 高寒草甸、高寒半荒漠和荒漠成分; 负载荷为蒿属、 禾本科、沙棘属等, 为高寒草原成分. 相对喜冷的高 寒草甸和半荒漠、荒漠成分与相对喜暖的高寒草原成 分分别居于第二主成分轴的两端, 表明 PCA 2 反映 了冷暖程度的变化. 正值表示趋向寒冷, 负值表示趋 向温暖.

\section{2 花粉谱、粒度和 IC 揭示的全新世气候变化}

根据塔若错 TRL11-2 孔的花粉组合、粒度与无 机碳酸盐的变化(图 4), 可以将该区全新世环境演化 分为 4 个阶段.

阶段 I(10200 8900 cal a BP) 花粉浓度很低, 平均 为 6400 粒/克, 具有缓慢上升趋势. 蒿属花粉含量下 降, 㳟科、麻黄属等干旱花粉和松属等乔木花粉含量 快速下降, 莎草科花粉含量上升. PCA $1, \mathrm{~A} / \mathrm{Cy}$ 值均 快速降低, 反映了这一时期流域湿度增大. $M z$ 和 IC 的快速降低, 指示由于湖泊水位快速上升, 水动力变 弱, 碳酸盐沉积析出能力下降. PCA 2 下降意味着流

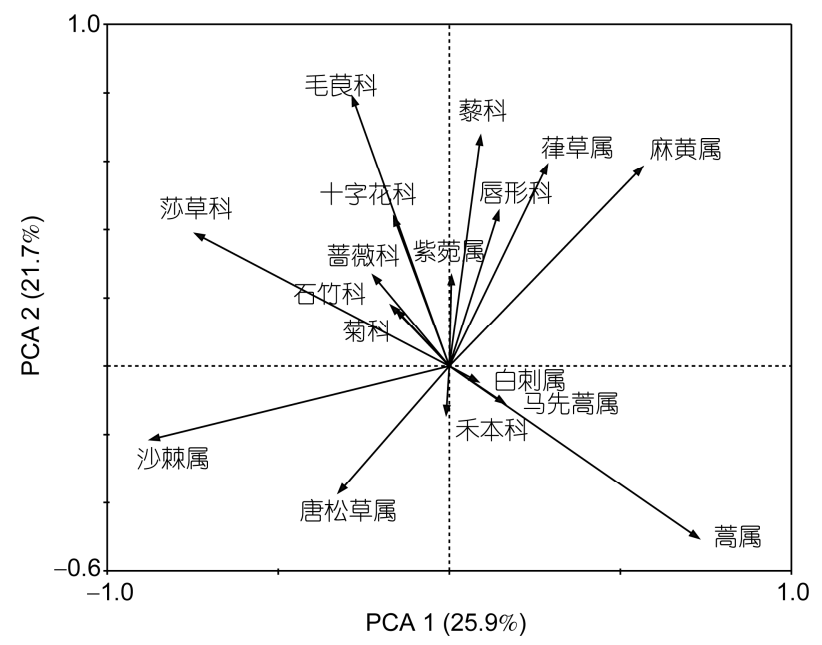

图 5 塔若错钻孔花粉主成分分析

PCA 1 和 PCA 2 分别解释了 $25.9 \%$ 和 $21.7 \%$ 的花粉科属信息
域由冷向暖发展. 尤其是 10200 9900 cal a BP 期间, 麻黄、莍科等花粉含量以及 $M z$, IC 等指标的快速变 化, 反映了气候由冷干变得暖湿.

阶段 II(8900 7400 cal a BP)蒿属花粉含量高, 莎 草科花粉含量为全序列最低, 湖区周围发育以蒿属 为主的草原. PCA 1 和 $\mathrm{A} / \mathrm{Cy}$ 出现序列中的高值, 反映 了湖区的干旱环境, 而相对高的 PCA 2 代表了当时 流域相对温暖.

阶段 III(7400 3300 cal a BP)可以分为 2 个亚阶 段. 7400 6500 cal a BP, 蒿属含量呈下降趋势, 莎草 科含量上升, 说明植被由高寒草原向高寒草甸或草 甸化草原演替. PCA 1 和 $\mathrm{A} / \mathrm{Cy}$ 下降, 反映了流域湿度 增加. 在 $7200 \mathrm{cal} \mathrm{a}$ BP 左右, PCA 2 出现高值, 而 PCA 1 和 A/Cy 都出现突然下降, 可能反映了一个强 冷湿事件. 在这个亚阶段, $M z$ 呈上升趋势, 与较强的 人湖补给有关(湿度增大反映的降水或温度升高带来 的较多冰川融水). $6500 \mathrm{cal} \mathrm{a} \mathrm{BP}$ 开始, $M z$ 迅速下降, 由于 PCA 1 指示的流域湿度已比较稳定, 沉积物粒 度迅速变细的原因可能与冰川融水减少, 水动力减 弱有关, 这也与 PCA 2 迅速上升代表的温暖程度减 弱相吻合. 至 $6300 \mathrm{cal} \mathrm{a} \mathrm{BP}$ 左右, IC 值降为 0 , 本文 的解释是当时湖泊有大量的淡水注人, 甚至湖泊不 再封闭, 碳酸盐等沉积物不能析出保存在沉积物 中 ${ }^{[29,36]}$, 这种条件一直维持到 $1100 \mathrm{cal} \mathrm{a} \mathrm{BP}$ 左右. 6500 3300 cal a BP, 蒿属的含量低, 平均只有 $23.6 \%$, 莎草科含量为全序列最高, 表明流域以高寒草甸或 草甸化草原为主. $\mathrm{A} / \mathrm{Cy}$ 和 PCA 1 略呈上升趋势, 但总 体值很低, 说明该时期塔若错地区依然比较湿润. 其 中, 4600 4200 cal a BP, A/Cy 出现高值, 反映了一个 短暂的干旱事件, $M z$ 在同期出现下降, 可能与降水 减少造成补给动力下降有关.

阶段 IV(3300 cal a BP 至今) 蒿属花粉含量呈增 加趋势, 莎草科花粉含量下降, 高寒草原植被发育. $\mathrm{A} / \mathrm{Cy}$ 和 PCA 1 值增大, 说明该时期塔若错地区整体

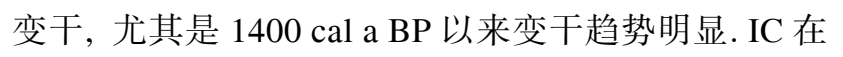
约 $1100 \mathrm{cal} \mathrm{a} \mathrm{BP}$ 开始出现, 并持续增加, 说明塔若错 已经封闭, 湖水水位的持续下降致使水中的碳酸盐 达到饱和状态析出并保留在沉积物中. PCA 2 在 3200 3000 cal a BP 和 1200 1000 cal a BP 值比较低, 指示了 2 个相对温暖时期. $2900 \mathrm{cal} \mathrm{a} \mathrm{BP}$ 左右出现的 PCA 2 上升和 $M z$ 增加, 可能是由于短暂变冷引起冰 川融水较少, 导致湖面突然下降引起水动力增强的 


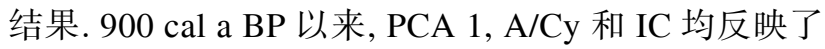
湖区向干旱化发展.

\section{3 塔若错环境变化的区域和全球意义}

比较塔若错与青藏高原其他地区以及亚洲中部 西风控制区早全新世湖泊沉积记录的气候环境变化 特点, 可以发现该区受西南季风影响较为明显. 10200 8900 cal a BP, 塔若错 PCA 1 和 PCA 2 指示了 气候由冷干变得暖湿, 与高原季风区和季风/西风过 渡区的湖泊记录具有较好的一致性. 在这一时期, 川 西地区拉龙错狍粉 PCA 1 快速增加, 气候向暖湿发 展 ${ }^{[10,38]}$. 高原东南部红原泥炭纤维素 $\delta^{13} \mathrm{C}$ 虽有波动, 但总体值偏负, 反映了季风强盛, 气候温暖湿润 ${ }^{[39]}$. 高原东北部青海湖记录表明, 乔木花粉含量增加, 气 候变得更为暖湿 ${ }^{[6]}$. 高原中部兹格塘错 $\mathrm{A} / \mathrm{C}$ 值波动较 大，但相对较高也反映了该时期的湿润环境 ${ }^{[40]}$. 高 原中部色林错的花粉记录发现, 9600 a BP $\left({ }^{14} \mathrm{C}\right.$ 年龄 $)$ 左右, 草原植被代替了高山稀疏植被, 气候变得暖 湿 ${ }^{[41]}$. 这与西风控制区巴里坤湖高含量的藜科花 粉 ${ }^{[42]}$ 和 Gun Nuur 低的湿度指数 ${ }^{[43]}$ 等所反映的普遍干 旱明显不同. 这说明全新世早期, 塔若错地区受西南 季风影响, 气候由冷干变得暖湿(图 6).

早全新世后期，塔若错湖芯记录在 8900 7400 cal a BP 出现相对干旱和温暖的特征, 这与季风控制 区暖湿的气候组合有明显差异，而与西风控制区较 为一致. 阿曼石笋记录 ${ }^{[45]}$ 反映出早中全新世季风强 盛, 气候暖湿. 云南洱海沉积物多指标分析 ${ }^{[46]}$, 青藏 高原东南部海登湖 ${ }^{[11]}$ 和拉龙错 ${ }^{[10]}$ 花粉记录也均指示 了早中全新世暖湿的气候特征. 西风控制区的新疆 乌伦古湖多环境代用指标综合分析，反映了 10000 $7000 \mathrm{cal} \mathrm{a} \mathrm{BP}$ 时期, 气候温暖干旱 ${ }^{[47]}$. 赛里木湖 9600 5500 cal a BP 发育典型的荒漠草原/草原植 被 ${ }^{[48]}$, 气候温暖偏干. 博斯腾湖花粉分析, 表明这一 地区早全新世气候干旱 ${ }^{[44]}$. 巴里坤湖在 $7900 \mathrm{cal} \mathrm{a}$ $\mathrm{BP}$ 之前, 植被以蔡科为主, 气候干旱 ${ }^{[42]}$. 亚洲中部 干旱区气候记录集成研究 ${ }^{[2]}$, 反映出 $8000 \mathrm{cal} \mathrm{a} \mathrm{BP} \mathrm{之}$ 前, 气候干旱. 托勒库勒湖 ${ }^{[49]}$ 地区全新世开始至 $7900 \mathrm{cal}$ a BP 时期, 发育荒漠植被, 气候干旱. Gun Nuur 湿度重建 ${ }^{[43]}$ 也反映出这一时期气候干旱的特征. 季风与西风过渡区这一时期的气候特征不尽相同, 如班公湖花粉记录 ${ }^{[8]}$ 均显示出这一时期, 气候温暖湿 润. 然而, 扎布耶茶卡沉积物 $\delta^{13} \mathrm{C}, \delta^{18} \mathrm{O}$ 和总有机碳
含量指示 10600 7200 cal a BP 气候暖干 ${ }^{[15]}$. 兹格塘 错 8700 7300 cal a BP低的 A/C 值反映了稀疏的植被, 干旱的气候条件 ${ }^{[40]}$. 高原东北部克鲁克湖地区 9500 $5500 \mathrm{cal} \mathrm{a} \mathrm{BP}$ 发育以藜科为主的荒漠植被, 花粉数据 PCA 分析也指示这一时期气候干旱 ${ }^{[13]}$.

青藏高原早全新世的气候转暖与 $30^{\circ} \mathrm{N}$ 夏季太阳 辐射增强 ${ }^{[50]}$ 具有密切联系. 在强烈的太阳辐射下, 包括塔若错地区的整个高原全新世初期温度均呈快 速上升趋势, 这与北大西洋地区数据集成所反映出 来的温度变化 ${ }^{[51]}$ 类似. 一方面, 气候变暖引起海陆 热力差异加大, 可能使季风增强, 为过渡区带来较多 的降水; 另一方面, 气温升高会加剧高原内陆冰雪的 消融，也使得湿度增加. 然而，塔若错在 8900 7400 cal a BP 呈现的干旱和相对温暖的特点, 与季风区早一 中全新世的暖湿特点不相一致, 其原因存在以下两 种可能:一是该区在太阳辐射的驱动下, 温度较高, 强盛的印度季风带来较丰富的降水, 但由于辐射强 烈, 蒸发作用强, 供植物生长所需要的水分反而较少; 二是由于北半球大陆仍有较大范围的冰盖, 西风环

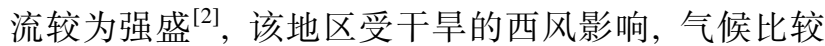
干旱. 亚洲干旱区湿度指数变化 ${ }^{[2]}$ 也指示了在 8000 cal a BP 之后, 气候才开始由干旱变得湿润. 考虑到 塔若错在 8900 7400 cal a BP 主要以干旱为主, 仅在 PCA 2 上显示了相对温暖的特点, 作者认为该时期的 干早更可能受西风区的环流影响.

塔若错地区在中全新世(6500 5600 cal a BP)最 为湿润，这通过 $\mathrm{A} / \mathrm{Cy}$ 和 PCA 1 值最低可以反映出来. 青藏高原季风区和过渡区的其他湖泊环境记录也反 映了这个特点，如高原中部的纳木错 7000 6000 cal a $\mathrm{BP}$ 干旱花粉指数 DI 值最低, 指示了气候最为湿润 ${ }^{[35]}$; 兹格塘错 $\mathrm{A} / \mathrm{C}$ 值在 7300 4400 cal a BP 值最高, 反映 了湿润的环境 ${ }^{[00]}$; 错鄂 TOC、元素、 $\delta^{13} \mathrm{C}$ 等多指标 分析, 表明 8560 5750 cal a BP, 气候温暖湿润 ${ }^{[7]}$. 高 原南部的沉错花粉 ${ }^{[12,52]}$ 、元素、TOC、粒度等 ${ }^{[52]}$ 均反 映了早中全新世的湿润环境; 高原东南部的海登湖 8000 6000 cal a BP 是其气候最适宜期 ${ }^{[11]}$ 等. 另外, 在印度 Thar 沙漠中的湖泊记录 ${ }^{[53]}$ 也指示了 7000 $6000 \mathrm{cal}$ a BP 的高湖面. 对于青藏高原季风与西风过 渡区而言，中全新世湿润可能是由于北半球大陆冰 盖消失，中高纬度温度升高，西风环流衰弱北撤，尚 为强盛的西南季风更为主要地控制这一区域，使得 气候比较湿润。 


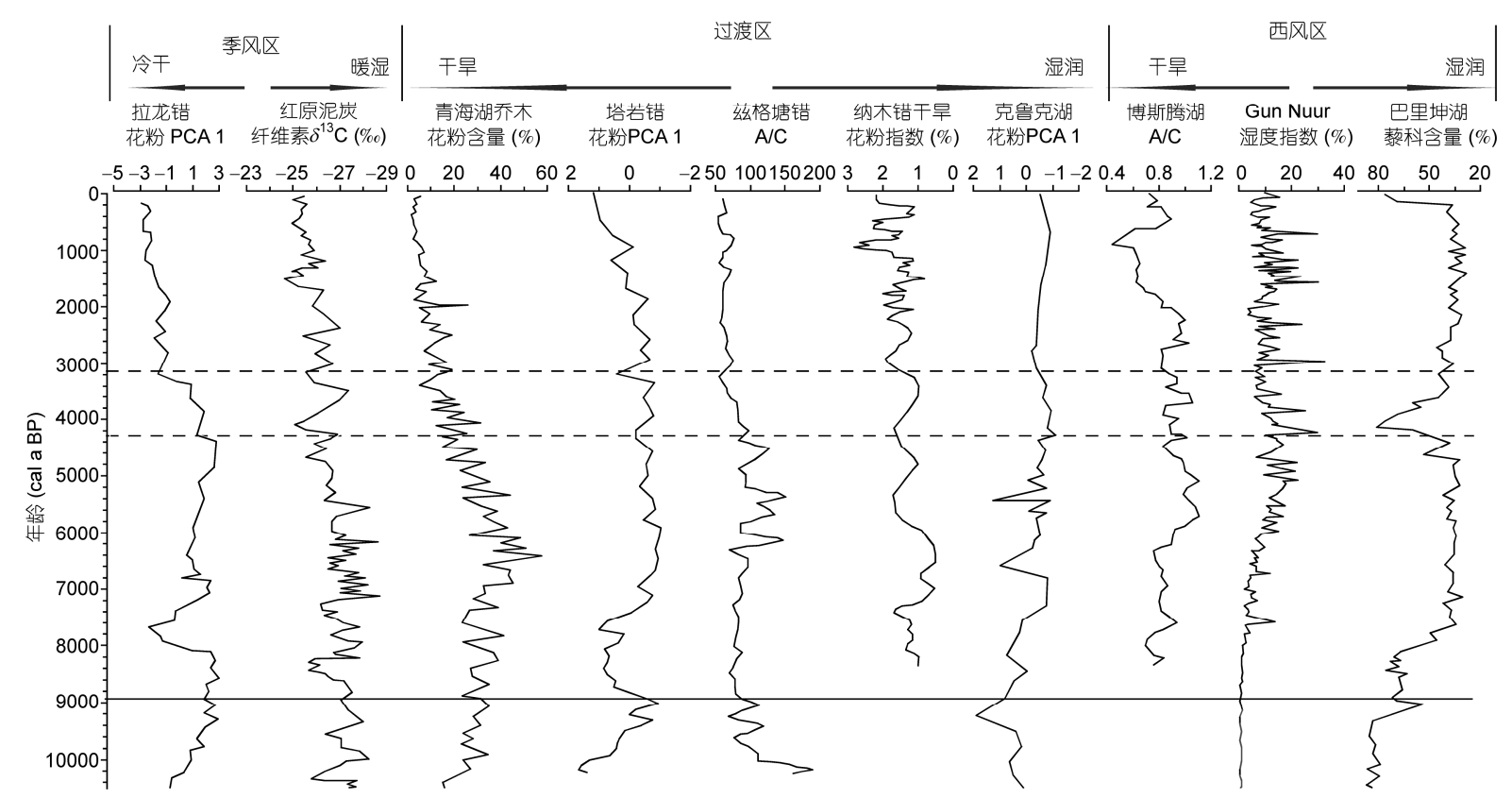

图 6 塔若错全新世湿度变化及其与临近区域湖泊记录的对比

虚线表示干旱事件. 季风区: 拉龙错主成分分析第一轴得分 PCA $1^{[10]}$, 红原泥炭纤维素有碳同位素 $\delta^{13} \mathrm{C}^{[39]}$; 过渡区: 青海湖乔木花粉含量 ${ }^{[6]}$, 塔 若错 PCA 1 得分, 兹格塘错高属与藜科花粉含量比值 $\mathrm{A} / \mathrm{C}^{[40]}$, 纳木错干旱花粉(藜科、十字花科、麻黄属、白刺属和柽柳科)百分比之和 ${ }^{[35]}$, 克鲁 克湖主成分分析得分 PCA $1^{[13]}$; 西风区: 博斯腾湖 $\mathrm{A} / \mathrm{C}^{[44]}$, Gun Nuur 湿度指数(湿生草原与针叶林花粉类型含量之和除以荒漠、中旱 生草原与桦木林花粉类型之和 ${ }^{[4]}$, 巴里坤湖藜科花粉百分含量 ${ }^{[42]}$

最湿润时期之后, 塔若错地区呈逐渐变干趋势, 并出现 3 次较大的干旱事件, 分别为 $4300 \mathrm{cal} \mathrm{a} \mathrm{BP}$ 左 右、3200 cal a BP 左右和 $1200 \mathrm{cal} \mathrm{a} \mathrm{BP}$ 左右. 其中 $4300 \mathrm{cal} \mathrm{a} \mathrm{BP}$ 左右的干旱事件在青藏高原的青海 湖 $^{[6]}$ 、克鲁克湖 ${ }^{[13]}$ 、错那 ${ }^{[54]}$ 、兹格塘错 ${ }^{[40]}$ 、松木希 错 ${ }^{[55]}$ 、班公湖 ${ }^{[8]}$, 中国东部的岱海 ${ }^{[56]}$ 、呼伦湖 ${ }^{[57]}$ 和湖 光岩玛珥湖 ${ }^{[58]}$, 中国西南部的董哥洞石笋 ${ }^{[16]}$, 西北 地区的巴里坤湖 ${ }^{[42]}$ 、博斯腾湖 ${ }^{[44]}$ 和托勒库勒湖 ${ }^{[49]}$ 等 均有记录. 这一事件不仅在中国广泛分布, 而且在阿

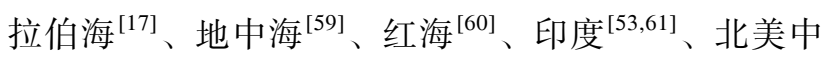
部 ${ }^{[62]}$ 和非洲 ${ }^{[63]}$ 等也有出现, 反映了这是一次全球性 的事件 ${ }^{[64]}$, 其原因与多种因素有关系, 如太阳活 动 ${ }^{[62,65]}$ 、太平洋 ${ }^{[62,66]}$ 和大西洋 ${ }^{[63]} \mathrm{SST}$ 的变化、火山活

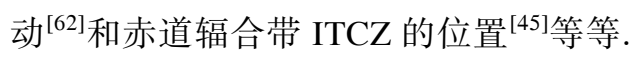

中晚全新世(6300 cal a BP)以来, 塔若错记录与 北大西洋记录(图 7)具有较好的对应. 其中 900 200, 1800 1400, 3100 2700, 4200 3800, 6300 5200 cal a BP 的寒冷时期分别对应了 Bond0 (LIA), 1, 2, 3 和 4 等事件 ${ }^{[67]}$. 这可能是中晚全新世北半球 $30^{\circ} \mathrm{N}$ 夏季太 阳辐射 ${ }^{[50]}$ 和印度季风强度 ${ }^{[17,65,68]}$ 明显减弱, 北大西 洋冷暖变化可以通过西风环流影响到塔若错地区,
从而引起塔若错地区的同步变化. 高原东南部红原泥 炭纤维素碳同位素研究 ${ }^{[40]}$ 也反映了全新世该地区与 北大西洋温度变化的遥相关关系. 位于塔若错东部同 属芫塘高寒草原区的纳木错也记录了晚全新世西风环 流对该地区的影响 ${ }^{[35]}$. 6300 900 cal a BP, 气候出现冷 湿的组合特征, 与西风区的气候特征具有一致性, 说 明了中晚全新世西风环流对该区气候有着显著的影响.

\section{5 结论}

通过对塔若错不同水深的湖泊表层沉积物和 TRL11-2 湖芯的花粉以及测年分析, 较为精细地重 建了该地区全新世以来的环境变化, 并初步讨论了 其对季风/西风环流的响应.

（1）塔若错不同水深表层沉积物花粉类型和含 量均表现出相对一致的特点, 反映了湖泊沉积物对 流域孢粉的富集以及在沉积过程中均匀分配的作用.

(2) 塔若错钻孔花粉样品 PCA 结果显示, 第一 轴将蒿属、禾本科、麻黄属、莍科等高寒草原、高寒 半荒漠和荒漠成分与莎草科、毛莨科、唐松草属等高 寒草甸成分分开, 能够明显地指示降水(或湿度)变化; 第二轴将莎草科、毛茛科、麻黄属、莍科等高寒草甸、 


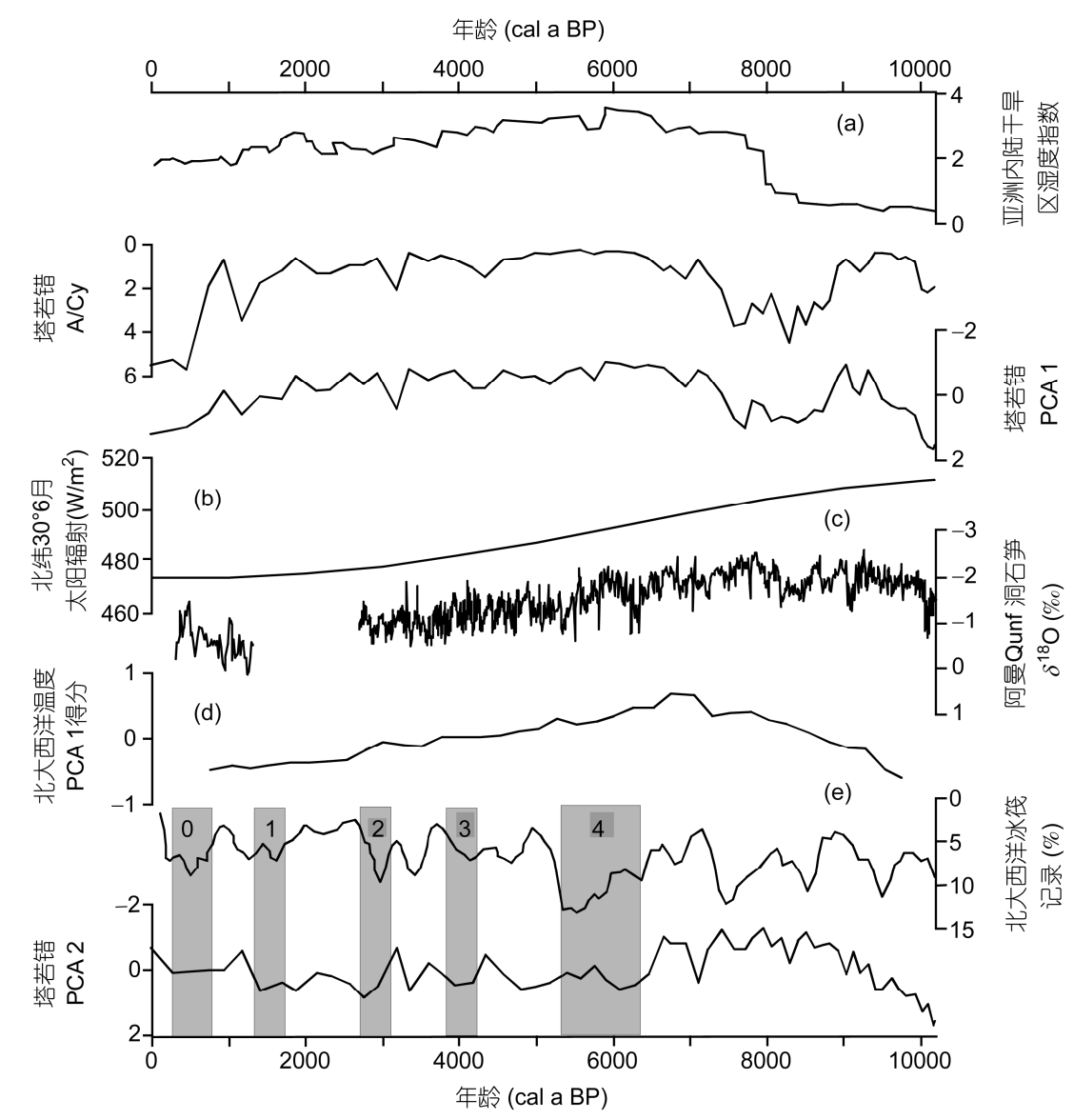

图 7 塔若错记录与气候驱动因素、季风区以及北大西洋地区记录的比较

(a) 亚洲内陆干旱区湿度指数 ${ }^{[2]}$; (b) 北纬 $30^{\circ}$ 处 6 月份太阳辐射的变化 ${ }^{[50]}$; (c) 阿曼石笋氧同位素记录 ${ }^{[17]}$; (d) 北大西洋地区温度偏差的主成分 分析得分 PCA $1^{[51]}$; (e) 北大西洋冰伐记录 ${ }^{[67]}$; 其他 A/Cy, PCA 2 和 PCA 1 记录(本文)

高寒半荒漠和荒漠成分与蒿属、禾本科等高寒草原成 分分开，可以指示相对温暖的程度，而 $\mathrm{A} / \mathrm{Cy}$ 比值能 够较好地反映草原与草甸的植被类型变化.

(3) 塔若错地区的全新世以来气候变化具有明 显的 4 个阶段: 全新世初期(10200 8900 cal a BP), 塔若错地区的植被由高寒草原向高寒草甸转换, 气 候由冷干开始向暖湿发展; 全新世早期(8900 7400 cal a BP), 植被经历了由高寒草甸到草原的转换, 气 候向偏干旱方向发展, 并具温暖的特征; 全新世中期 (7400 3300 cal a BP), 植被经历了高寒草原-高寒草 甸或草甸化草原的转换, 气候以冷湿为主; 全新世晚 期(3300 cal a BP 至今), 植被逐渐被高寒草原植被取
代, 气候变得寒冷干旱.

（4）全新世中晚期 6300 5200, 4200 3800, 3100 $2700,1800 \sim 1400$ 和 900 200 cal a BP 的寒冷阶段, 与 北大西洋 Bond 4, 3, 2, 1 和 0(LIA)具有较好的对应, 反映了中晚全新世, 太阳辐射和印度季风减弱, 西风 环流增强, 北大西洋冷暖变化可以通过西风环流影 响到塔若错地区, 从而引起塔若错地区的同步变化.

总体来看, 塔若错在全新世早期的干旱偏暖特 征, 与中晚全新世的寒冷和西风环流具有密切联系, 而全新世中期的湿润特点更主要受印度季风的影响. 因此, 塔若错的湖泊沉积环境记录对于进一步阐述 西风/季风在该地区的影响程度具有非常重要的意义. 


\section{参考文献}

1 Wu G X, Liu Y M, He B, et al. Thermal controls on the Asian summer monsoon. Sci Rep, 2012, 2: 404

2 Chen F H, Yu Z, Yang M L, et al. Holocene moisture evolution in arid central Asia and its out-of-phase relationship with Asian monsoon history. Quat Sci Rev, 2008, 27: 351-364

3 An Z S, Colman S M, Zhou W J, et al. Interplay between the Westerlies and Asian monsoon recorded in Lake Qinghai sediments since 32 ka. Sci Rep, 2012, 2: 619

4 Yao T D, Masson-Delmotte V, Gao J, et al. A review of climatic controls on $\delta^{18} \mathrm{O}$ in precipitation over the Tibetan Plateau: Observations and simulations. Rev Geophys, 2013, 51: 525-548

5 Gasse F, Arnold M, Fontes J C, et al. A 13000-year climate record from western Tibet. Nature, 1991, 353: 742-745

6 Shen J, Liu X Q, Wang S M, et al. Palaeoclimatic changes in the Qinghai Lake area during the last 18000 years. Quat Int, 2005, 136: $131-140$

7 Wu Y H, Lücke A, Jin Z D, et al. Holocene climate development on the central Tibetan Plateau: A sedimentary record from Cuoe Lake. Paleogeogr Paleoclimatol Paleoecol, 2006, 234: 328-340

8 Van Campo E, Cour P, Huang C. Holocene environmental changes in Bangong Co basin (Western Tibet). Part 2: The pollen record. Paleogeogr Paleoclimatol Paleoecol, 1996, 120: 49-63

9 Herzschuh U, Birks H J B, Mischke S, et al. A modern pollen-climate calibration set based on lake sediments from the Tibetan Plateau and its application to a Late Quaternary pollen record from the Qilian Mountains. J Biogeogr, 2010, 37: 752-766

10 Kramer A, Herzschuh U, Mischke S, et al. Holocene treeline shifts and monsoon variability in the Hengduan Mountains (southeastern Tibetan Plateau), implications from palynological investigations. Paleogeogr Paleoclimatol Paleoecol, 2010, 286: 23-41

11 唐领余, 沈才明, 廖洤标, 等. 末次盛冰期以来西藏东南部的气候变化一一西藏东南部的花粉记录. 中国科学 D辑：地球科学, 2004, 34: $436-442$

12 Lü H Y, Wu N Q, Liu K B, et al. Modern pollen distributions in Qinghai-Tibetan Plateau and the development of transfer functions for reconstructing Holocene environmental changes. Quat Sci Rev, 2011, 30: 947-966

13 Zhao Y, Yu Z, Chen F, et al. Holocene vegetation and climate history at Hurleg Lake in the Qaidam Basin, northwest China. Rev Palaeobot Palynology, 2007, 145: 275-288

14 Herzschuh U, Kramer A, Mischke S, et al. Quantitative climate and vegetation trends since the late glacial on the northeastern Tibetan Plateau deduced from Koucha Lake pollen spectra. Quat Res, 2009, 71: 162-171

15 Wang R L, Scarpitta S C, Zhang S C, et al. Later Pleistocene/Holocene climate conditions of Qinghai-Xizhang Plateau (Tibet) based on carbon and oxygen stable isotopes of Zabuye Lake sediments. Earth Planet Sci Lett, 2002, 203: 461-477

16 Wang Y, Cheng H, Edwards R L, et al. The Holocene Asian monsoon: Links to solar changes and North Atlantic climate. Science, 2005, 308: $854-857$

17 Fleitmann D, Burns S J, Mudelsee M, et al. Holocene forcing of the Indian monsoon recorded in a stalagmite from southern Oman. Science, 2003, 300: 1737-1739

18 Chen F H, Chen J H, Holmes J, et al. Moisture changes over the last millennium in arid central Asia: A review, synthesis and comparison with monsoon region. Quat Sci Rev, 2010, 1055-1068

19 高由禧. 东亚季风的若干问题. 北京：科学出版社, 1962. 1-49

20 王苏民，窦鸿身. 中国湖泊志. 北京：科学出版社, 1998. 402

21 中国科学院青藏高原综合科学考察队. 西藏植被. 北京：科学出版社. 1988

22 Reimer P J, Baillie M G L, Bard E, et al. IntCal09 and Marine09 radiocarbon age calibration curves, 0-50000 years cal BP. Radiocarbon, 2009, 51: 11-50

23 王伏雄，钱南芬，张玉龙，等. 中国植物花粉形态. 第 2 版. 北京：科学出版社, 1995

24 席以珍, 宁建长. 中国干旱半干旱地区花粉形态研究. 玉山生物学报, 1994, 11: 119-191

25 Grimm E C. TGView. Illinois State Museum Reasearch Collection Center. Version 2.0.2, Springfield, 2004

26 Birks H J B. Quantitative palaeoenvironmental reconstructions. In: Maddy D, Brew J S, eds. Statistical Modelling of Quaternary Science Data. Technical Guide, vol.5. Cambridge: Quaternary Research Association, 1995. 161-254

27 Ter Braak C J F. Canoco-a FORTRAN program for canonical community ordination by (partial) (detrended) (canonical) correspondence analysis, principal components analysis and redundancy analysis (version 2.1). Technical Report. LWA-88-02. Wageningen: GLW, 1988. 95

28 Ter Braak C J F, Smilauer P. CANOCO 4.5. Biometris. Wageningen: Wageningen University and Research Center, 2002. 500 
29 Watanabea T, Matsunakab T, Nakamurac T, et al. Last glacial-Holocene geochronology of sediment cores from a high-altitude Tibetan lake based on $\mathrm{AMS}^{14} \mathrm{C}$ dating of plant fossils: Implications for paleoenvironmental reconstructions. Chem Geol, 2010, 277: 21-29

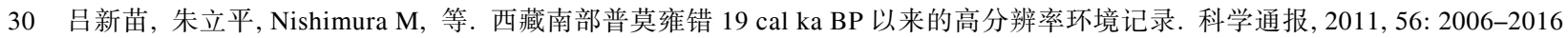

31 El-Moslimany A P. Ecological significance of common nonarboreal pollen: Examples from drylands of the Middle East. Rev Palaeobot Palynol, 1990, 64: 343-350

32 Herzschuh U. Reliability of pollen ratios for environmental reconstructions on the Tibetan Plateau. J Biogeogr, 2007, 34: 1265-1273

33 Zhao Y, Liu H, Li F, et al. Application and limitations of the Artemisia/Chenopodiaceae pollen ratio in arid and semi-arid China. Holocene, 2012, 22: 1385-1392

34 Dieter D, Pavel E T, Bernd W, et al. Late glacial and Holocene vegetation, Indian monsoon and westerly circulation in the Trans-Himalaya recorded in the lacustrine pollen sequence from Tso Kar, Ladakh, NW India. Paleogeogr Paleoclimatol Paleoecol, 2009, 279: $172-185$

35 Li Q, Lü H, Zhu L, et al. Pollen-inferred climate changes and vertical shifts of alpine vegetation belts on the northern slope of the Nyainqentanglha Mountains (central Tibetan Plateau) since 8.4 ka BP. Holocene, 2011, 21: 939-950

36 Zhao Y, Herzschuh U. Modern pollen representation of source vegetation in the Qaidam Basin and surrounding mountains, north-eastern Tibetan Plateau. Veget Hist Archaeobot, 2009, 18: 245-260

37 Fowell S J, Hansen B C S, Peck J A, et al. Mid to late Holocene climate evolution of the Lake Telmen Basin, North Central Mongolia, based on palynological data. Quat Res, 2003, 353-363

38 Kramer A, Herzschuh U, Mischke S, et al. Late glacial vegetation and climate oscillations on the southeastern Tibetan Plateau inferred from the Lake Naleng pollen profile. Quat Res, 2010, 73: 324-335

39 Hong Y T, Hong B, Lin Q H, et al. Correlation between Indian Ocean summer monsoon and North Atlantic climate during the Holocene. Earth Planet Sci Lett, 2003, 211: 371-380

40 Herzschuh U, Winter K, Wünnemann B, et al. A general cooling trend on the central Tibetan Plateau throughout the Holocene recorded by the Lake Zigetang pollen spectra. Quat Int, 2006, 154: 113-121

41 孙湘君, 杜乃秋, 陈因硕, 等. 西藏色林错湖泊沉积物的花粉分析. 植物学报, 1993, 35: 943-950

42 An C B, Lu Y, Zhao J, et al. A high-resolution record of Holocene environmental and climatic changes from Lake Balikun (Xinjiang, China): Implications for central Asia. Holocene, 2012, 22: 43-52

43 Feng Z D, Ma Y Z, Zhang H C, et al. Holocene climate variations retrieved from Gun Nuur lake-sediment core in the northern Mongolian Plateau. Holocene, 2013, 23: 1721-1730

44 Wünnemann B, Mischke S, Chen F, et al. A Holocene sedimentary record from Bosten Lake, China. Paleogeogr Paleoclimatol Paleoecol, 2006, 234: 223-238

45 Fleitmann D, Burns S J, Mangini A, et al. Holocene ITCZ and Indian monsoon dynamics recorded in stalagmites from Oman and Yemen (Socotra). Quat Sci Rev, 2007, 26: 170-188

46 沈吉, 杨丽原, 羊向东, 等. 全新世以来云南洱海流域气候变化与人类活动的湖泊沉积记录. 中国科学 $\mathrm{D}$ 辑: 地球科学, 2004,34 : 130-138

47 蒋庆丰, 沈吉, 刘兴起, 等. 西风区全新世以来湖泊沉积记录的高分辨率古气候演化. 科学通报, 2007, 52: 1042-1049

48 蒋庆丰, 季俊峰, 沈吉, 等. 赛里木湖狍粉记录的亚洲内陆干旱西风区全新世植被与气候变化. 中国科学: 地球科学, 2013, 2: 243-255

49 An C B, Zhao J J, Tao S C, et al. Dust variation recorded by lacustrine sediments from arid central Asia since 15 cal ka BP and its implication for atmospheric circulation. Quat Res, 2011, 75: 566-573

50 Berger A, Loutre M F. Insolation values for the climate of the last 10 million years. Quat Sci Rev, 1991, 10: 297-317

51 Kaplan M R, Wolfe A P. Spatial and temporal variability of Holocene temperature in the North Atlantic region. Quat Res, 2006, 65: $223-231$

52 Zhu L P, Zhen X L, Wang J B, et al. A 30000-year record of environmental changes inferred from Lake Chen Co, Southern Tibet. J Paleolimnol, 2009, 42: 343-358

53 Prasad S, Enzel Y. Holocene paleoclimates of India. Quat Res, 2006, 66: 442-453

54 Shen C, Liu K B, Morrill C, et al. Ecotone Shift and major droughts during the mid-late Holocene in the central Tibetan Plateau. Ecology, 2008, 89: 1079-1088

55 Van Campo E, Gasse F. Pollen- and diatom-inferred climatic and hydrological changes in Sumxi Co Basin (Western Tibet) since 13000 a BP. Quat Res, 1993, 39: 300-313

56 Xiao J, Xu Q, Nakamura T, et al. Holocene vegetation variation in the Daihai Lake region of north-central China: A direct indication of the Asian monsoon climatic history. Quat Sci Rev, 2004, 23: 1669-1679 
57 Wen R, Xiao J, Chang Z, et al. Holocene climate changes in the mid-high-latitude-monsoon margin reflected by the pollen record from Hulun Lake, northeastern Inner Mongolia. Quat Res, 2010, 73: 293-303

58 王淑云, 吕厚远, 刘嘉麒, 等. 湖光岩玛珥湖高分辨率狍粉记录揭示的早全新世适宜期环境特征. 科学通报, 2007, 52: 1285-1291

59 Roberts N, Eastwood W J, Kuzucuoğlu C, et al. Climatic, vegetation and cultural change in the eastern Mediterranean during the mid-Holocene environmental transition. Holocene, 2011, 21: 147-162

60 Arz H W, Lamy F, Pätzold J. A pronounced dry event recorded around 4.2 ka in brine sediments from the northern Red Sea. Quat Res, 2006, 66: 432-441

61 Enzel Y, Ely L L, Mishra S, et al. High-resolution Holocene environmental changes in the Thar Desert, northwestern India. Science, 1999, 284: $125-128$

62 Booth R K, Jackson S T, Forman S L, et al. A severe centennial-scale drought in midcontinental North America 4200 years ago and apparent global linkages. Holocene, 2005, 15: 321-328

63 Gasse F. Hydrological changes in the African tropics since the Last Glacial Maximum. Quat Sci Rev, 2000, 19: 189-211

64 Gupta A K, Anderson D M, Overpeck J T. Abrupt changes in the Asian southwest monsoon during the Holocene and their links to the North Atlantic Ocean. Nature, 2003, 42: 354-357

65 Gupta A K, Das M, Anderson D M. Solar influence on the Indian summer monsoon during the Holocene. Geophys Res Lett, 2005, 32: L17703

66 Roberts M, Henry H. Rapid environmental change in African and South American tropics around 4000 years before present: A review. Earth Sci Rev, 2004, 66: 217-260

67 Bond G, Kromer B, Beer J, et al. Persistent solar influence on North Atlantic climate during the Holocene. Science, 2001, 294: 2130-2136

68 Overpeck J, Anderson D, Trumbore S, et al. The southwest Indian Monsoon over the last 18000 years. Clim Dyn, 1996, 12: 213-225

\section{补充材料}

\section{表 S1 塔若错钻孔 TRL11-2 测年结果 \\ 图 S1 塔若错表层沉积物与周围表土的花粉组合}

本文的以上补充材料见网络版 csb.scichina.com. 补充材料为作者提供的原始数据, 作者对其学术质量和内容负责. 